\title{
Effects of Low Intensity Ultrasound on the Chondrogenic Differentiation of Adult Stem Cells From Adipose Tissue
}

\author{
Hajar Shafaei, ${ }^{1}$ Abolghasem Esmaeili, ${ }^{2}$ Mohammad Mardani, ${ }^{3}$ Shahnaz Razavi, ${ }^{3}$ Batol Hashenibeni, ${ }^{3}$ \\ Mohsen Nasr-Esfahani, ${ }^{4}$ and Ebrahim Esfandiary ${ }^{3,}{ }^{*}$ \\ ${ }^{1}$ Department of Anatomical Sciences, Faculty of Medicine, Tabriz University of Medical Sciences, Tabriz, IR Iran \\ ${ }^{2}$ Department of Biology, Faculty of Sciences, University of Isfahan, Isfahan, IR Iran \\ ${ }^{3}$ Department of Anatomical Sciences and Molecular Biology, School of Medicine, Isfahan University of Medical Sciences, Isfahan, IR Iran \\ ${ }^{4}$ Pathology Lab of Alzahra Hospital, Faculty of Sciences, Isfahan University of Medical Sciences, Isfahan, IR Iran \\ "Corresponding author: Ebrahim Esfandiary, Department of Anatomical Sciences and Molecular Biology, School of Medicine, Isfahan University of Medical Sciences, Isfahan, IR \\ Iran. E-mail: esfandiari@med.mui.ac.ir
}

Received 2015 February 5; Accepted 2015 May 20.

\begin{abstract}
Background: Adult stem cells from adipose tissue can be used in tissue engineering because of their capacity to differentiate into chondrocytes. Low intensity ultrasound (LIUS) as a physical chondrogenic inducer differentiates adipose stem cells (ASC) into chondrocyte the same as transforming growth factor- $\beta$ (TGF $\beta)$. However the stage of differentiation and hypertrophy of chondrocytes by LIUS have not yet been studied.

Objectives: The aim of this study was to determine the effect of LIUS on hypertrophic states of differentiated chondrocytes.

Materials and Methods: In this experimental study, ASCs were cultured in chondrogenic differentiation medium $(10 \mathrm{ng} / \mathrm{mL}$ of $\operatorname{TGF} \beta$ ) with or without LIUS stimulation for two weeks. The ultrasound signal was applied at an intensity of $200 \mathrm{~mW} / \mathrm{cm}^{2}$ for 10 min/day. For evaluation, the mRNA expression of collagen type X, alkaline phosphatase, Runx2 and Runx2II, were studied using quantitative gene expression method. Histologic and immunohistochemistry evaluations were performed. The data were analyzed by one way ANOVA (Tukey's).

Results: The mRNA expression of collagen type X, and alkaline phosphatase, Runx2 and Runx2II were decreased markedly by the LIUS stimulation, whereas the expression of these genes drastically increased when TGF $\beta$ applied alone or with LIUS. LIUS containing cultures showed lower hypertrophic protein expression (alkaline phosphatase and Indian hedgehog) as compared with the controls.

Conclusions: Our results showed that LIUS suppresses hypertrophic chondrocyte formation and that LIUS induced chondrocytes are more suitable than TGF $\beta$ induced ones due to low expression of hyperthrophic markers in cartilage tissue engineering for clinical applications.
\end{abstract}

Keywords: Adipose Stem Cells (ASCs), Chondrocyte, Chondrogenesis, Low Intensity Ultrasound

\section{Background}

Hyaline cartilage plays a crucial role during normal skeletal development [1]. Transient hyaline cartilage forms the initial models of bones comprising the appendicular, axial skeletons and permanent articular cartilage in joints $[2,3]$.

Articular cartilage damage is major health problem in the world. Cartilage defects may be due to trauma, mechanical stress, or genetic factors, all of which can lead to osteoarthritis of the joint $[4,5]$. However, cartilage has a limited self-repair capacity due to avascularity and lack of innervation. Current treatments such as surgery or implantation of autologous chondrocytes [6-9] are not capable to restore hyaline cartilage in joints.

Mesenchymal stem cells (MSCs) have a multilineage differentiation capacity into cells such as adipocytes, osteoblasts, and chondroblasts $[9,10]$. MSCs have been isolated from several tissues including bone marrow, adipose tissue, muscles, deciduous teeth, umbilical cord blood, synovium, brain, blood cells and vessels [11]. Bone marrow is a source frequently used for mesenchymal stem cells [12]. Adult human Adipose stem cells (ASC) can be harvested readily, safely, and abundance by modern liposuction techniques [13-15].

Mesenchymal stem cells (MSCs) have chondrogenic potential with unwanted hypertrophic tendency under transforming growth factor- $\beta$ (TGF $\beta$ ) supplemented media [16]. In fetus, during endochondral bone formation TGF $\beta$ superfamily, parathyroid hormone-like peptide (PTHrP) and Indian hedgehog (Ihh)) regulate chondrogenesis and the onset of hypertrophy [17-19]. Studies showed

Copyright (c) 2016, Zahedan University of Medical Sciences. This is an open-access article distributed under the terms of the Creative Commons Attribution-NonCommercial 4.0 International License (http://creativecommons.org/licenses/by-nc/4.0/) which permits copy and redistribute the material just in noncommercial usages, provided the original work is properly cited. 
that in vitro MSCs chondrogenesis protocols may result in expression of hyaline cartilage components associated with early onset of hypertrophic markers such as collagen type $\mathrm{X}$ and alkaline phosphatase [20-23]. MSCs that were differentiated by common in vitro protocols and transplanted to ectopic sites underwent alterations related to endochondral ossification instead of a stable chondrogenic phenotype [24]. In recent years huge efforts have been done to generate hyaline cartilage constructs in in vitro that structurally and functionally mimic normal in vivo permanent hyaline cartilage [25]. So far the inhibition of hypertrophic differentiation of MSC during chondrogenic induction has not been studied interventionally [26].

During joint formation of embryo, mechanical factors play important role in permanent cartilage formation [27]. Different types of mechanical loading were studied on in vitro chondrogenesis $[28,29]$. Among mechanical strains, Pulsed ultrasound (LIPUS) has chondrogenic effect on chondrocytes and MSCs in in vitro and in vivo and these studies showed positive effect of LIPUS on extacelluar matix production [30-32]. Ultrasound waves in body tissues can result in micromechanical events at the cellular level [33]. As ultrasound has some advantages such as lowcost, safe in comparison to other mechanical forces and also ultrasound is easy to apply for possible future clinical applications [34], we applied LIUS for inducing chondrogenesis in ASC. We showed that LIUS as a physical inducer work better than $\mathrm{TGF} \beta$, in differentiating adipose tissue adult stem cells into chondrocytes by expression of collagen type 2 and aggrecan [35].

\section{Objectives}

Our hypothesis is application of LIUS on MSC may lead to obtain stable chondrocytes phenotype.

\section{Materials and Methods}

\subsection{ASCs Isolation and Culture}

Informed consent and local ethical committee approval was obtained for the use of adipose tissue specimens for this research. ASCs were isolated from subcutaneous adipose tissue that was harvested from female patients (21 - 38 years) undergoing abdomen elective surgical procedures. All experiments were performed on three sets of samples.

Cells were isolated from adipose tissue and characterized using methods previously described with minor modifications [36]. Briefly, the obtained tissue was washed with phosphate-buffered saline (PBS) to remove red blood cells, chopped into small pieces of about $25-50 \mathrm{~mm}^{3}$, and the extracellular matrix was digested for 60 minutes at $37^{\circ} \mathrm{C}$ with collagenase I $(0.5 \mathrm{mg} / \mathrm{mL})$ for each gram of adipose tissue (Sigma, St. Louis, MO) in PBS. The ASC-containing cell suspension was centrifuged at $600 \mathrm{~g}$, and the pellet was resuspended in culture medium, which was composed of Dulbecco's modified Eagle's medium (DMEM, Sigma) supplemented with $500 \mu \mathrm{g} / \mathrm{mL}$ streptomycin sulfate(Sigma), 600 Lg/mL penicillin (Sigma), and 10\% placental human serum [11]. Cultures were washed with PBS buffer after 24 hour plating to remove unattached cells and erythrocytes, and then re-fed with fresh medium [11,37]. Cultures were maintained at $37^{\circ} \mathrm{C}$ with $5 \% \mathrm{CO}_{2}$ and fed two times per week. ASCs were characterized as we reported previously [11]. We also in our previous work, studied viability and growth rate of cells [11].

For pellet culture, ASCs were differentiated in $15 \mathrm{~mL}$ Falcon tubes. ASC pellets were formed by centrifuging $2 \times 105$ cells at $500 \times \mathrm{g}$ in serum-free basal chondrogenic medium consisting of high glucose DMEM (DMEM-HG; Gibco), 10 - 7 $\mathrm{M}$ dexamethasone (Sigma, St. Louis, MO), $200 \mu \mathrm{M}$ ascorbic acid 2-phosphate (Sigma), 1\% BSA (sigma), ITS (Gibco), and $1 \%$ streptomycin sulfate (Sigma)/penicillin (Sigma). Four groups (control, ultrasound, TGF $\beta$ and ultrasound/TGF $\beta$ ) of pellets were cultured in basal chondrogenic medium for 14 days. In this study for adjusting experiment, TGF- $\beta 3$ (10 ng/mL) was added to basal chondrogenic medium for TGF $\beta$ containing cultures.

\subsection{Low-Intensity Ultrasound (LIUS) Treatment}

The low intensity ultrasound (LIUS) device (Novin, Iran) with continuous wave at $1 \mathrm{MHz}$ and intensity of 200 $\mathrm{mW} / \mathrm{cm}^{2}$ was applied for 10 minutes per day in ultrasound cultures $[35,38]$. The distance between transducer and cultures was determined by the Sarvazyan method [39-41].

\subsection{Gene Expression}

RNA samples were prepared after chondrogenic differentiation. Pellets were disrupted in liquid nitrogen using a small pestle and then RNA isolated using TRIzol reagents (Invitrogen). One microgram of poly (A) + RNA was reverse transcribed to cDNA using RevertAid First Strand cDNA Synthesis Kit (Fermentase) with random hexamer primers. The real-time polymerase chain reaction was performed using SYBR Green kit (ABI, USA) and the Choromo 4 quantitative Real time RT PCR detection System (BioRad). Undiluted cDNA $(2 \mu \mathrm{L})$ was used in $20 \mu \mathrm{L}$ PCR mix. Relative gene expression of collagen type $\mathrm{X}$, alkaline phosphatase, Runx2 and Runx2 type II of control and treatment cultures were determined and normalized to housekeeping gene expression (18S) and then compared with untreated (day 0) ASCs. 
Primers were designed for each gene using the Beacon Designer 7 software (Premier Biosoft International, Palo Alto, CA, USA). Primers used in Real-time RT PCR are listed in Table 1 . The triplicate expression level of each target gene was calculated as $2^{-\Delta \Delta \mathrm{Ct}}$, as previously described [42].

\subsection{Histological and Immunohistochemical Analysis}

Pellets were harvested and fixed in 10\% buffered formalin for 2 hour at room temperature. The fixed pellets, after tissue processing were embedded in paraffin. For immunohistochemical assessment, sections after post fixation with acetone for 5 minutes were washed in PBS (PH 7.5) for 30 minutes at $37^{\circ} \mathrm{C}$ and then peroxidase activity was blocked by 30 minutes incubation in $0.3 \% \mathrm{H}_{2} \mathrm{O}_{2}$ in ethanol. After two 5- minutes rinses with PBS the pellets were pretreated with $1 \mathrm{mg}$ pepsin (Sigma) ( $1 \mathrm{~mL}$ in of $0.5 \mathrm{M}$ acetic acid) for 40 minutes at $37^{\circ} \mathrm{C}$ for optimal antigen retrieval and then were washed 5- minutes with PBS. The procedure followed by overnight incubation at room temperature with the indicated antibodies in PBS containing $0.1 \%$ BSA. Primary antibodies to, alkaline phosphatase (Serotec, Kidlington, UK) and Indian hedgehog (Ihh) (Abcam, Cambridge, UK) were used (1 to 100).

All incubations were performed in a humidified chamber. After extensive washing with PBS to remove residual primary antibody, reactivity was detected using secondary antibody (horse raddish proxidase, DAKO Cytomation) for 60 minutes at room temperature. Peroxidase activity was visualized by diaminobenzidine) DAB (as substrate with 10 minutes incubation (DAB; DAKO cytomation). The reaction was stopped by rinsing water and the sections were counterstained with Hemotoxylin (Merck). The sections were dehydrated through graded alcohols, cleared with xylene, and permanently mounted.

Data were obtained from three independent donors. For statistical analysis, the data were presented as Means \pm SEM. Significances were tested by one way ANOVA (Tukey's) in Graph pad prism program. $\mathrm{P}<0.05$ was considered to be statistically significant.

\section{Results}

The gene expression of collagen type $\mathrm{X}$, alkaline phosphatase, Runx2 and Runx2 type II was determined by realtime RT PCR of cultured ASCs and differentiated ASCs into chondrocytes with TGF $\beta$ and LIUS (Figure 1A - D). The relative gene expression of hypertrophic markers (collagen type X, ALP, Runx2 and Runx2 type II) in TGF $\beta$ treated cultures, significantly up-regulated by $685 \pm 1$ (Figure $1 \mathrm{~A}$ ), 24 \pm 3 (Figure 1B), $6280 \pm 398$ (Figure 1C) and $96 \pm 14$ (Figure 1D) respectively. The relative expression of collagen type $X$,
ALP, Runx2 and Runx2 type II in ultrasound treated cultures were $39 \pm 3$ (Figure 1A), $1.7 \pm 0.8$ (Figure 1B), $481 \pm 3$ (Figure $1 \mathrm{C}$ ) and $20 \pm 2$ (Figure $1 \mathrm{D}$ ) respectively. Also addition ultrasound to $\mathrm{TGF} \beta$ reduced the expression of collagen type $\mathrm{X}, \mathrm{ALP}$, Runx2 and Runx2 type II genes by 2.2 (Figure 1A), 3.1 (Figure 1B), 5.2 (Figure 1C) and 1.2 (Figure 1D) fold respectively. The values of hypertrophic gene in LIUS treated cultures were significantly lower than TGF $\beta$ containing cultures $(\mathrm{P}<0.001)$.

Moreover these data show that ultrasound can significantly decrease hypertrophic gene expression effects of TGF containing medium on ASCs (Table 2 ).

\subsection{Immunohistochemistry Results}

The effects of ultrasound, $\operatorname{TGF} \beta$ and combination of them on hypertrophic proteins production is evaluated by alkaline phosphatase (ALP) and Ihh immunostaining. Control cultures expressed some ALP protein (Figure 2A). Interestingly LIUS treatment eliminated expression of ALP (Figure $2 \mathrm{~B}$ ) as compared to the control cultures. In LIUS-TGF treated cultures (Figure 2D) versus TGF $\beta$ treated cultures as well. Strong protein expression of ALP was found in pellets that did not receive LIUS (Figure $2 \mathrm{~A}$ and $\mathrm{C}$ ). TGF $\beta$ containing cultures showed more ALP positive area in inset micrographs revealed differences of treated cultures with control cultures. In natural cartilage from costal cartilage was positive for ALP (Figure 2E).

In the staining of Ihh protein, we observed immunopositive area in control and TGF containing cultures (Figure $3 \mathrm{~A}$ and $\mathrm{C}$ ). The results of this study showed that Ihh protein is expressed in LIUS and LIUS-TGF $\beta$ treated cultures (Figure $3 \mathrm{~B}$ and $\mathrm{D}$ ) versus control and $\mathrm{TGF} \beta$ treated cultures (Figure $3 \mathrm{~A}$ and $\mathrm{C}$ ) respectively. In human costal cartilage Ihh protein was observed in endochondrol ossification areas (Figure 3E).

\section{Discussion}

Tissue engineering approaches for reconstruction of the cartilage is a challenging problem in orthopedic surgery. Mesenchymal stem cells (MSCs) are currently evaluated for possible usage in this area. Many studies have been done to optimize protocols for generation of stable chondrocytes without hypertrophy for transplantation purposes [16]. The aim of the current study was formulation of an innovative physical approach for chondrogenic differentiation instead of chemical TGF $\beta$. Both induction methods (LIUS and TGF $\beta$ ) capable to induce differentiation of ASCs to chondrocytes by expressing collagen type II proteins. Inhibition of chondrocyte maturation results of this 
Table 1. The Primers is Used for Real-Time RT PCR in This Study

\begin{tabular}{|c|c|c|}
\hline Primer & Primer Sequence & Bp \\
\hline $18 \mathrm{~S}$ & & 153 \\
\hline $\mathrm{R}$ & $5^{\prime}$ - GTAACCCGTTGAACCCCATT- $3^{\prime}$ & \\
\hline $\mathrm{F}$ & $5^{\prime}$ - CCATCCAATCGGTAGTAGCG $3^{\prime}$ & \\
\hline Col10 & & 225 \\
\hline $\mathrm{F}$ & $5^{\prime}$-CACTACCCAACACCAAGACA- $3^{\prime}$ & \\
\hline $\mathrm{R}$ & $5^{\prime}$ - CTGGTTTCCCTACAGCTGAT- $3^{\prime}$ & \\
\hline ALP & & 197 \\
\hline $\mathrm{F}$ & $5^{\prime}$ - ATGAGGCGGTGGAGATGG- $3^{\prime}$ & \\
\hline $\mathrm{R}$ & $5^{\prime}$ - CATACAGGATGGCAGTGAAGG- $3^{\prime}$ & \\
\hline Runx2 & & 165 \\
\hline $\mathrm{F}$ & $5^{\prime}$ - CCGTCCATCCACTCTACCACC- $3^{\prime}$ & \\
\hline $\mathrm{R}$ & $5^{\prime}$ - AGGCAGAAGTCAGAGGTG-3' & \\
\hline Runx2II & & 156 \\
\hline F & $5^{\prime}$ - ATGCTTCATTCGCCTCAC-3' & \\
\hline $\mathrm{R}$ & $5^{\prime}$ - ACTGCTTGCAGCCTTAAAT- $3^{\prime}$ & \\
\hline
\end{tabular}

Table 2. Statistical Results Summary of Gene Expressions of Col10, ALP, Runx2, Runx2II in Control and Treatment Groups ${ }^{\mathrm{a}}$

\begin{tabular}{|c|c|c|c|c|c|c|c|}
\hline Analyzed & Control vs US & Control vs TGF & Control vs US-TGF & US vs TGF & US vs US-TGF & TGF vs US-TGF & $\mathbf{R 2}$ \\
\hline Col10 & ns & $* * *$ & ns & $* * *$ & $*$ & $* *$ & 0.56 \\
\hline ALP & $* * *$ & ns & $* *$ & $* * *$ & ns & *** & 0.68 \\
\hline Runx2 & ns & $* * *$ & ns & $* * *$ & ns & $* * *$ & 0.9 \\
\hline Runx2II & ns & $* *$ & ns & $* * *$ & $* * *$ & ns & 0.58 \\
\hline
\end{tabular}

Abbreviations: ALP, alkaline phosphatase; Col10, collagen type 10; Runx2, runt-related transcription factor-2; Runx2II, runt-related transcription factor-2 type II; TGF, transforming growth factor; US, ultrasound; ns, not significant.

${ }^{\mathrm{a}}$ Means $\mathrm{P}<0.05 ;{ }^{* *}$ means $\mathrm{P}<0.005 ;{ }^{* * *}$ means $\mathrm{P}<0.0005$ and

study confirms our pervious collagen type II protein expression results. LIUS induces production of early stage extracelluar matrix of cartilage and more collagen type IIA than collagen type IIB [35]. In cartilage development collagen type IIA is the splice variant of type II collagen that has been found in prechondrocytes and immature chondrocytes [43]. It seems that the splicing protein TASR-1 attributes in removing exon 2 from Col2A [44]. Probably ultrasound mediated these effects via integrins and activativation of MAPK signaling and phosphorylation pathway [45]. Previous studies showed that phosphorylation modulates splicing proteins function [46] and stress stimulus resulted in changes splicing factors [46-49]. Comparison of gene and protein expression results of TGF $\beta$ treated cultures showed that TGF $\beta$ treated constructs are mature cartilage tissue than LIUS treated constructs. In fact it seems that LIUS differentiated constructs are in early stage of chondrogenesis than TGF constructs. It is possible ultrasound decreases hypertrophic markers of chondrogenesis by decreasing of TGF $\beta 1$ and TGF $\beta 2$ [50].

In skeletogenesis isoforms of Runx2 express differently in permanent cartilage. Runx2I was highly expressed in osteoprogenitor cells and active osteoblasts [51]. Moreover in Runx-|- mice intramembranous and endochondral ossification is blocked [52]. These data were in accordance with our results that the expression of total Runx2 was too high in TGF cultures than LIUS cultures of present study. While relative gene expression of Runx2II in all cultures about 50 times lower than total Runx2 and therefore amount of Runx2II inhibition by LIUS is not comparable with relative gene expression Runx2.

The results of this study are in agreement with the study that they applied ultrasound parameters close to parameters of our study [38]. LIUS parameters of this study 
A

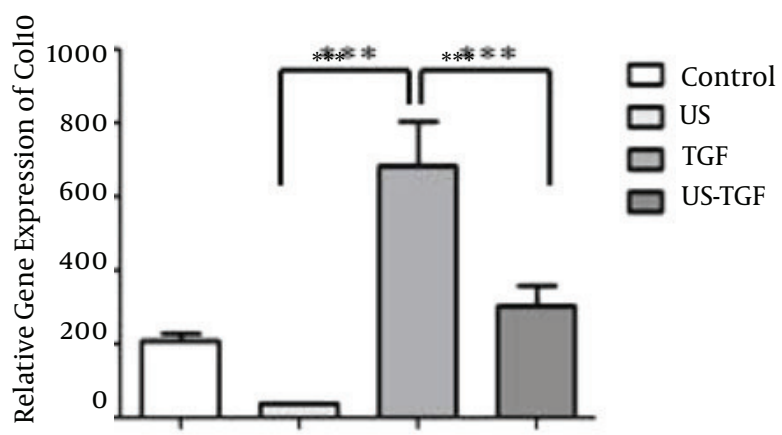

C

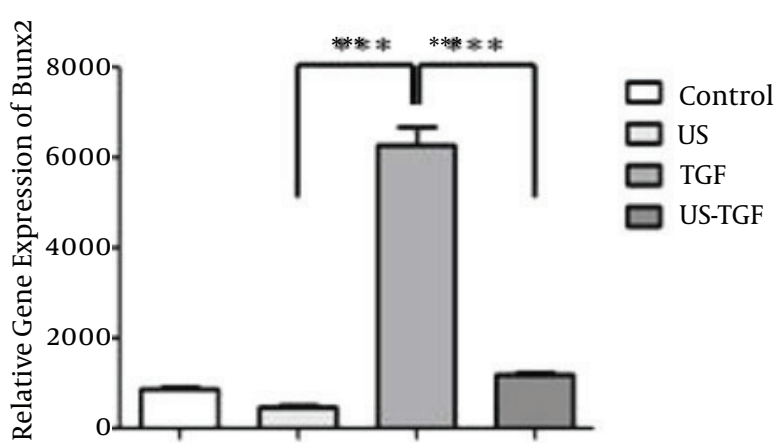

B

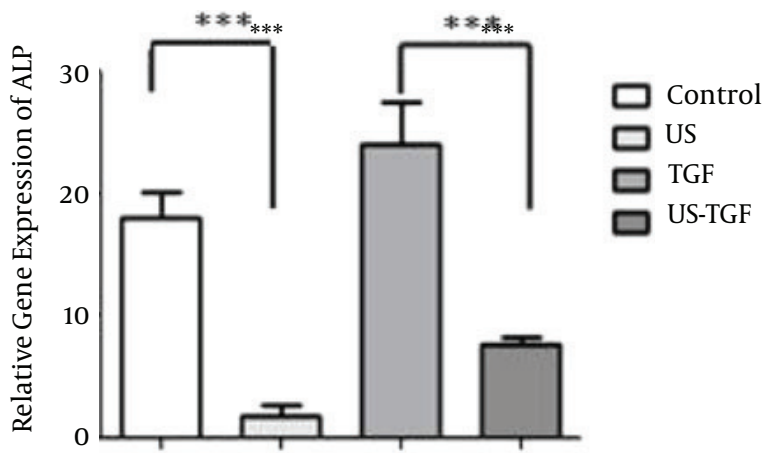

D

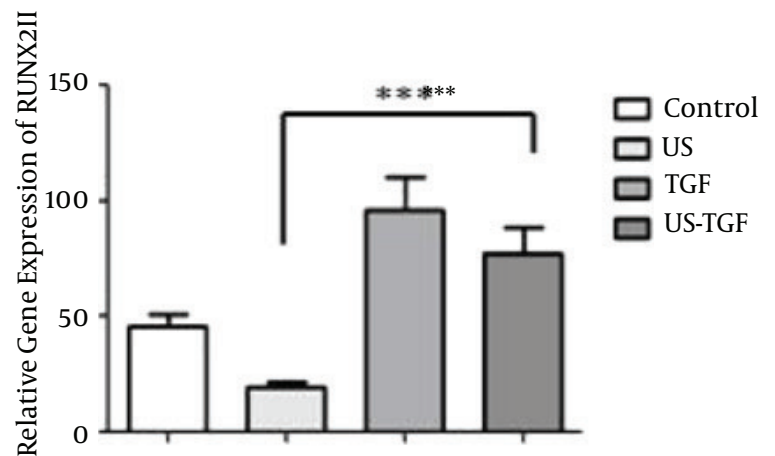

The cells were cultured for up to 14 days in four group's control, LIUS, TGF $\beta$ and LIUS-TGF $\beta$. In untreated and treated cultures the relative mRNA expression of hypertrophic chondrogenic markers to $18 \mathrm{~S}$ housekeeping gene were determined using real-time RT PCR. The relative gene expressions for hypertrophic markers: Col10 A, Alkaline phosphatase; $\mathrm{B}$, Runx2; C and Runx2II D have been shown. Values are Mean $\pm \mathrm{SEM}, \mathrm{n}=3$. ${ }^{* * *}$ Means is $\mathrm{P}<0.001$. TGF $\beta$, transforming growth factor $\beta$; TGF $\beta$ concentration: 10 ng/mL; LIUS, low-intensity ultrasound. LIUS dose: $10 \mathrm{~min} /$ day; Col X, collagen type X; ALP, alkaline phosphatase; Runx2; RunxII, runt-related transcription factor-2 type

are different from other studies (intensity $\left(30 \mathrm{~mW} / \mathrm{cm}^{2}\right)$ and frequency $(1.5 \mathrm{MHz})$ but they showed chondrogenic differentiation without focus on hypertrophic markers evaluations. However complexity of interpretation of results mainly is due to differences in stem cell source, cell culture methods, ultrasound parameters and evaluation methods. In this regard we examined chondrogenic effects of ultrasound in same condition on ASC and BMSC and we observed different behavior of these cells against ultrasound (unpublished data). Previous studies on BMSC showed the effects of ultrasound on chondrogenesis [31]. Zhang et al. reported anatomical origins of MSCs have profound influences on the proliferative and osteogenic capacity of MSCs and BMSC inherently suspected to chondroosteogenic lineage [53]. Therefore, ASCs from adipose tissue probably might have lower tendencyto osteogenic lineage than BMSC. For evaluation of different ultrasound wave parameters further studies is necessary.

This study focused on studying of hypertrophic genes and proteins after treatment by TGF $\beta$ and LIUS. We showed that using TGF $\beta$ leads to differentiated chondrocytes with unwanted production of hypertrophic markers. We found that LIUS can down regulate hypertrophic markers such as collagen type X, ALP, Runx2 and Runx2 type II in ASCs and also LIUS could inhibit hypertrophic effects of TGF $\beta$. Recently other study evaluated the prevention of the hypertrophy of differentiated stem cell to chondrocytes and they showed collagens type 2 and $\mathrm{X}$ decrease by microgravity [54]. Further investigations are needed to clarify the mechanism of lower stages of LIUS differentiated chondrocytes than TGF $\beta$.

In conclusion, our results indicate LIUS induced chondrocytes are suitable for tissue engineering purposes. This study provides a new vision to cartilage tissue engineering 
Figure 2. Micrographs of Alkaline Phosphatase Immunostaining
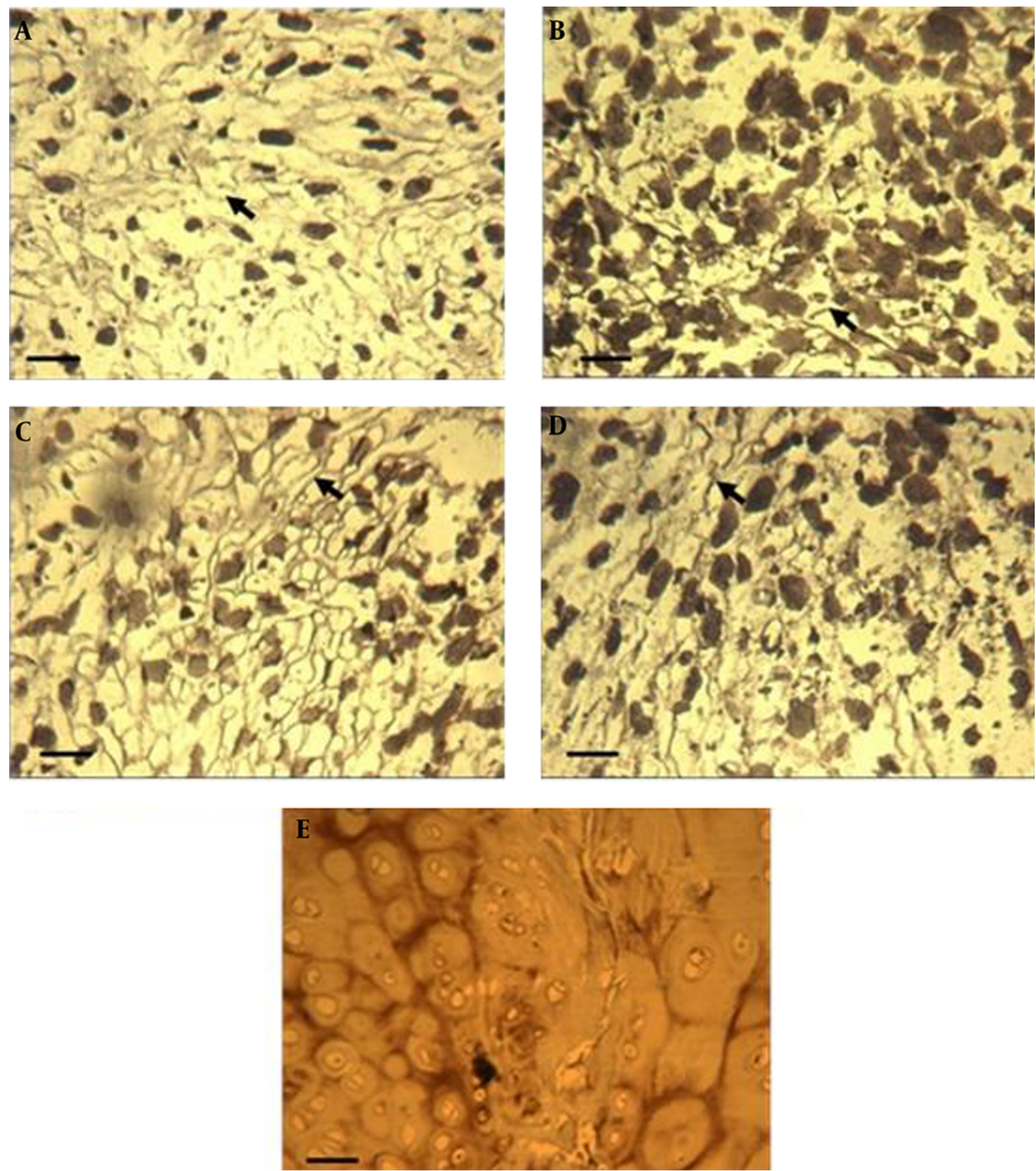

Alkaline phosphatase (ALP) staining of ASCs pellets after 14 days of culture and hyaline cartilage. A, control pellets; B, cultures treated with low-intensity ultrasound, C, TGF $\beta$ treated pellet cultures; D, low-intensity ultrasound stimulation plus TGF $\beta$. scale bar: $50 \mu \mathrm{m}$; Arrows show ALP proteins in insets, Native human costal cartilage was used as the positive control (E) scale bar: $200 \mu \mathrm{m}$. TGF $\beta$, transforming growth factor- $\beta$; TGF $\beta$ concentration: $10 \mathrm{ng} / \mathrm{mL}$; LIUS, low-intensity ultrasound; LIUS dose: 10 min/day.

by appropriate use of ultrasound for decreasing of hypertrophic markers especially Ihh protein as intrachondral os- sification protein. Therefore, the LIUS induced chondrocytes may have permanent cartilage cell properties. How- 

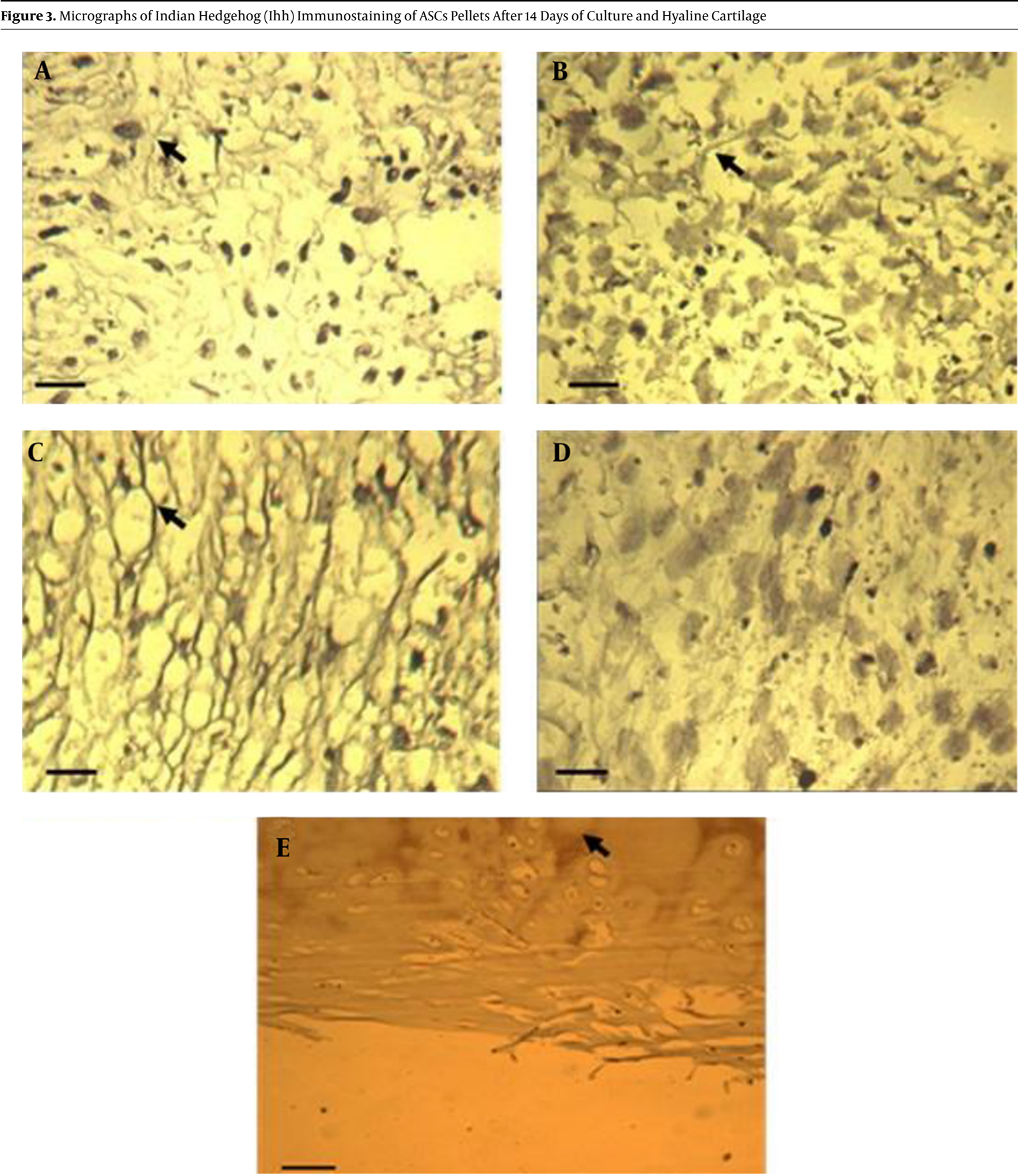

A, Control cultures; B, cultures treated with low-intensity ultrasound; C, TGF $\beta$ treated pellets; D, low-intensity ultrasound in combination with TGF $\beta$; E, hyaline cartilage as a positve. Control. Arrows show Ihh proteins around lacunas in treated cultures and hyaline cartilage. Scale bar for untreted and treated pellet cultures with LIUS, TGF $\beta$ and LIUS-TGF $\beta$ : $50 \mu \mathrm{m}$. Scale bar for hyaline cartilage: $200 \mu \mathrm{m}$. TGF $\beta$, transforming growth factor- $\beta$; TGF $\beta$ concentration: $10 \mathrm{ng} / \mathrm{mL}$; LIUS, low-intensity ultrasound; LIUS dose: 10 $\min /$ day.

ever, it is needed to find out specific marker for permanent cartilage and also to optimize LIUS parameters (distance between ultrasound probe and cells, exposure time, frequency and intensity of waves) in in vitro and in vivo. More- 
over continued studies on chondrogenic signaling pathways of ultrasound are vital to understanding its mechanism on chondrogenesis in comparison to $\operatorname{TGF} \beta$.

\section{Acknowledgments}

This study was supported by grant of the Isfahan University of Medical Sciences (Grant No. 178057). The authors thank Dr Fereshteh Haghighat for providing human adipose tissue.

\section{Footnotes}

Authors' Contribution: All authors had equal role in design, work, statistical analysis and manuscript writing.

Funding/Support: Isfahan University of Medical Sciences.

\section{References}

1. Ross MH, Pawlina W. Histology: A text and atlas with correlated cell and molecular biology. 6 ed. Philadelphia: Lippincott Williams and Wilkins; 2010. pp.164-79.

2. Koopman WJ, Moreland LW. Arthritis and allied conditions: A textbook of rheumatology (two volume set). 15 ed. Washington D.C.: LWW Press; 2004.

3. Jeffery WR. Evolution and development, volume 86 (Current topics in developmental biology). San Diego: Academic press; 2009. pp. 15-6.

4. Buckwalter JA. Articular cartilage injuries. Clin Orthop Relat Res. 2002(402):21-37. [PubMed: 12218470].

5. O'Driscoll SW. Preclinical cartilage repair: current status and future perspectives. Clin Orthop Relat Res. 2001(391 Suppl):S397-401. [PubMed: 11603722].

6. Brittberg M, Lindahl A, Nilsson A, Ohlsson C, Isaksson O, Peterson L. Treatment of deep cartilage defects in the knee with autologous chondrocyte transplantation. N Engl J Med. 1994;331(14):889-95. doi: 10.1056/NEJM199410063311401. [PubMed: 8078550].

7. Chu CR, Convery FR, Akeson WH, Meyers M, Amiel D. Articular cartilage transplantation. Clinical results in the knee. Clin Orthop Relat Res. 1999(360):159-68. [PubMed: 10101321].

8. Minas T, Nehrer S. Current concepts in the treatment of articular cartilage defects. Orthopedics. 1997;20(6):525-38. [PubMed: 9195635].

9. Wakitani S, Goto T, Pineda SJ, Young RG, Mansour JM, Caplan AI, et al. Mesenchymal cell-based repair of large, full-thickness defects of articular cartilage. J Bone Joint Surg Am. 1994;76(4):579-92. [PubMed: 8150826].

10. Friedenstein AJ, Chailakhjan RK, Lalykina KS. The development of fibroblast colonies in monolayer cultures of guinea-pig bone marrow and spleen cells. Cell Tissue Kinet. 1970;3(4):393-403. [PubMed: 5523063].

11. Shafaei H, Esmaeili A, Mardani M, Razavi S, Hashemibeni B, NasrEsfahani $\mathrm{MH}$, et al. Effects of human placental serum on proliferation and morphology of human adipose tissue-derived stem cells. Bone Marrow Transplant. 2011;46(11):1464-71. doi:10.1038/bmt.2010.313. [PubMed: 21217787].

12. Warden SJ, Favaloro JM, Bennell KL, McMeeken JM, Ng KW, Zajac JD, et al. Low-intensity pulsed ultrasound stimulates a boneforming response in UMR-106 cells. Biochem Biophys Res Commun. 2001;286(3):443-50. doi: 10.1006/bbrc.2001.5412. [PubMed: 11511078].
13. Zuk PA, Zhu M, Mizuno $\mathrm{H}$, Huang J, Futrell JW, Katz AJ, et al. Multilineage cells from human adipose tissue: implications for cell-based therapies. Tissue Eng. 2001;7(2):211-28. doi 10.1089/107632701300062859. [PubMed: 11304456].

14. Zuk PA, Zhu M, Ashjian P, De Ugarte DA, Huang JI, Mizuno H, et al Human adipose tissue is a source of multipotent stem cells. Mol Biol Cell. 2002;13(12):4279-95. doi:10.1091/mbc.E02-02-0105. [PubMed: 12475952].

15. Locke M, Windsor J, Dunbar PR. Human adipose-derived stem cells: isolation, characterization and applications in surgery. ANZ J Surg. 2009;79(4):235-44. doi: 10.1111/j.1445-2197.2009.04852.x. [PubMed: 19432707].

16. Hennig T, Lorenz H, Thiel A, Goetzke K, Dickhut A, Geiger F, et al Reduced chondrogenic potential of adipose tissue derived stromal cells correlates with an altered TGFbeta receptor and BMP profile and is overcome by BMP-6. J Cell Physiol. 2007;211(3):682-91. doi: 10.1002/jcp.20977. [PubMed: 17238135].

17. Vortkamp A, Lee K, Lanske B, Segre GV, Kronenberg HM, Tabin CJ. Regulation of rate of cartilage differentiation by Indian hedgehog and PTH-related protein. Science. 1996;273(5275):613-22. [PubMed: 8662546].

18. Shum L, Coleman CM, Hatakeyama Y, Tuan RS. Morphogenesis and dysmorphogenesis of the appendicular skeleton. Birth Defects Res $C$ Embryo Today. 2003;69(2):102-22. doi: 10.1002/bdrc.10012. [PubMed: 12955856].

19. Goldring MB, Tsuchimochi K, Ijiri K. The control of chondrogenesis. J Cell Biochem. 2006;97(1):33-44. doi: 10.1002/jcb.20652. [PubMed: 16215986].

20. Mueller MB, Fischer M, Zellner J, Berner A, Dienstknecht T, Prantl L, et al. Hypertrophy in mesenchymal stem cell chondrogenesis: effect of TGF-beta isoforms and chondrogenic conditioning. Cells Tissues Organs. 2010;192(3):158-66. doi: 10.1159/000313399. [PubMed: 20407224]

21. Sekiya I, Vuoristo JT, Larson BL, Prockop DJ. In vitro cartilage formation by human adult stem cells from bone marrow stroma defines the sequence of cellular and molecular events during chondrogenesis. Proc Natl Acad Sci U S A. 2002;99(7):4397-402. doi 10.1073/pnas.052716199. [PubMed: 11917104].

22. Weiss S, Hennig T, Bock R, Steck E, Richter W. Impact of growth factors and PTHrP on early and late chondrogenic differentiation of human mesenchymal stem cells. J Cell Physiol. 2010;223(1):84-93. doi 10.1002/jcp.22013. [PubMed: 20049852]

23. Winter A, Breit S, Parsch D, Benz K, Steck E, Hauner H, et al. Cartilagelike gene expression in differentiated human stem cell spheroids: a comparison of bone marrow-derived and adipose tissue-derived stromal cells. Arthritis Rheum. 2003;48(2):418-29. doi: 10.1002/art.10767. [PubMed: 12571852].

24. Bertram H, Boeuf S, Wachters J, Boehmer S, Heisel C, Hofmann MW, et al. Matrix metalloprotease inhibitors suppress initiation and progression of chondrogenic differentiation of mesenchymal stromal cells in vitro. Stem Cells Dev. 2009;18(6):881-92. doi: 10.1089/scd.2008.0306. [PubMed: 19327011].

25. Bobick BE, Chen FH, Le AM, Tuan RS. Regulation of the chondrogenic phenotype in culture. Birth Defects Res CEmbryo Today. 2009;87(4):35171. doi: 10.1002/bdrc.20167. [PubMed: 19960542].

26. Schmitt B, Ringe J, Haupl T, Notter M, Manz R, Burmester GR, et al. BMP2 initiates chondrogenic lineage development of adult human mesenchymal stem cells in high-density culture. Differentiation. 2003;71(9-10):567-77. doi: 10.1111/j.1432-0436.2003.07109003.x. [PubMed: 14686954].

27. Nowlan NC, Sharpe J, Roddy KA, Prendergast PJ, Murphy P. Mechanobiology of embryonic skeletal development: Insights from animal models. Birth Defects Res C Embryo Today. 2010;90(3):203-13. doi: 10.1002/bdrc.20184. [PubMed: 20860060]. 
28. Zhang J, Wang JH. The effects of mechanical loading on tendonsan in vivo and in vitro model study. PLoS One. 2013;8(8):e71740. doi: 10.1371/journal.pone.0071740. [PubMed: 23977130].

29. Henrionnet C, Wang Y, Roeder E, Gambier N, Galois L, Mainard D, et al. Effect of dynamic loading on MSCs chondrogenic differentiation in 3-D alginate culture. Biomed Mater Eng. 2012;22(4):209-18. doi: 10.3233/BME-2012-0710. [PubMed: 22785364].

30. Parvizi J, Wu CC, Lewallen DG, Greenleaf JF, Bolander ME. Lowintensity ultrasound stimulates proteoglycan synthesis in rat chondrocytes by increasing aggrecan gene expression. J Orthop Res. 1999;17(4):488-94. doi:10.1002/jor.1100170405. [PubMed: 10459753].

31. Schumann D, Kujat R, Zellner J, Angele MK, Nerlich M, Mayr E, et al. Treatment of human mesenchymal stem cells with pulsed low intensity ultrasound enhances the chondrogenic phenotype in vitro. Biorheology. 2006;43(3-4):431-43. [PubMed: 16912415].

32. El-Bialy $\mathrm{T}$, Uludag $\mathrm{H}$, Jomha $\mathrm{N}$, Badylak SF. In vivo ultrasoundassisted tissue-engineered mandibular condyle: a pilot study in rabbits. Tissue Eng Part C Methods. 2010;16(6):1315-23. doi: 10.1089/ten.TEC.2009.0564. [PubMed: 20233011].

33. Binderman I, Zor U, Kaye AM, Shimshoni Z, Harell A, Somjen D. The transduction of mechanical force into biochemical events in bone cells may involve activation of phospholipase A2. Calcif Tissue Int 1988;42(4):261-6. [PubMed: 2840180].

34. Schumann D, Kujat R, Nerlich M, Angele P. Mechanobiological conditioning of stem cells for cartilage tissue engineering. Biomed Mater Eng. 2006;16(4 Suppl):S37-52. [PubMed:16823112].

35. Shafaei H, Esfandiari E, Esmaeili A, Razavi S, Hashemibeni B, Nasr Esfahani MH, et al. Optimizing a novel method for low intensity ultrasound in chondrogenesis induction. Adv Biomed Res. 2013;2:79. doi: 10.4103/2277-9175.120867. [PubMed: 24520547].

36. Knippenberg M, Helder MN, Doulabi BZ, Semeins CM, Wuisman PI, Klein-Nulend J. Adipose tissue-derived mesenchymal stem cells acquire bone cell-like responsiveness to fluid shear stress on osteogenic stimulation. Tissue Eng. 2005;11(11-12):1780-8. doi: 10.1089/ten.2005.11.1780. [PubMed: 16411823]

37. Knippenberg M, Helder MN, de Blieck-Hogervorst JM, Wuisman PI, Klein-Nulend J. Prostaglandins differentially affect osteogenic differentiation of human adipose tissue-derived mesenchymal stem cells. Tissue Eng. 2007;13(10):2495-503. doi: 10.1089/ten.2006.0420. [PubMed: 17655490].

38. Lee HJ, Choi BH, Min BH, Son YS, Park SR. Low-intensity ultrasound stimulation enhances chondrogenic differentiation in alginate culture of mesenchymal stem cells. Artif Organs. 2006;30(9):707-15. doi: 10.1111/j.1525-1594.2006.00288.x. [PubMed: 16934100].

39. Sarvazyan AP, Pashovkin TN, Shilnikov GV, editors. An extremely simple and rapid method for registration of ultrasonic field patterns. Ultrasonics International. 1985; London. Oxford ButterworthHeinemann; pp. 324-8.

40. Bennett GS. A New Method for the Visualization and Measurement of Ultrasonic Fields. J Acous Soc America. 1952;24(5):470-4. doi: 10.1121/1.1906921.

41. Shiran MB, editor. Determination of ultrasound beam profile and spatial peak intensities from feild pattern by the Sarvazyan method. 5th biomedical engineering conference. 2014; Tehran. Iran University of Sciences and Technology.

42. Esmaeili A, Zaker SR. Differential expression of glycine receptor subunit messenger RNA in the rat following spinal cord injury. Spinal Cord. 2011;49(2):280-4. doi: 10.1038/sc.2010.109. [PubMed: 20733588].

43. McAlinden A, Havlioglu N, Sandell LJ. Regulation of protein diversity by alternative pre-mRNA splicing with specific focus on chondrogenesis. Birth Defects Res C Embryo Today. 2004;72(1):51-68. doi: 10.1002/bdrc.20004. [PubMed: 15054904].

44. Matsushita H, Blackburn ML, Klineberg E, Zielinska-Kwiatkowska A, Bolander ME, Sarkar G, et al. TASR-1 regulates alternative splicing of collagen genes in chondrogenic cells. Biochem Biophys Res Commun. 2007;356(2):411-7. doi: 10.1016/j.bbrc.2007.02.159. [PubMed: 17367759].

45. Takeuchi R, Ryo A, Komitsu N, Mikuni-Takagaki Y, Fukui A, Takagi Y, et al. Low-intensity pulsed ultrasound activates the phosphatidylinositol 3 kinase/Akt pathway and stimulates the growth of chondrocytes in three-dimensional cultures: a basic science study. Arthritis Res Ther. 2008;10(4):R77. doi:10.1186/ar2451. [PubMed: 18616830].

46. Stamm S. Regulation of alternative splicing by reversible protein phosphorylation. J Biol Chem. 2008;283(3):1223-7. doi: 10.1074/jbc.R700034200. [PubMed: 18024427].

47. van der Houven van Oordt W, Diaz-Meco MT, Lozano J, Krainer AR, Moscat J, Caceres JF. The MKK(3/6)-p38-signaling cascade alters the subcellular distribution of hnRNP A1 and modulates alternative splicing regulation. J Cell Biol. 2000;149(2):307-16. [PubMed:10769024].

48. Shin C, Feng Y, Manley JL. Dephosphorylated SRp38 acts as a splicing repressor in response to heat shock. Nature. 2004;427(6974):553-8. doi: 10.1038/nature02288. [PubMed: 14765198]

49. Kronenberg HM. Developmental regulation of the growth plate. Nature. 2003;423(6937):332-6. doi: 10.1038/nature01657. [PubMed: 12748651].

50. Shafaei H, Baghernezhad H. Ultrasound Effect on Gene Expression of Sex Determining Region Y-box 9 (SOX9) and Transforming Growth Factor $\beta$ Isoforms in Adipose Stem Cells. Zahedan J Res Med Sci. 2015.

51. Choi KY, Lee SW, Park MH, Bae YC, Shin HI, Nam S, et al.Spatio-temporal expression patterns of Runx2 isoforms in early skeletogenesis. Exp Mol Med. 2002;34(6):426-33. doi: 10.1038/emm.2002.60. [PubMed: 12526084].

52. Komori T, Yagi H, Nomura S, Yamaguchi A, Sasaki K, Deguchi K, et al. Targeted disruption of Cbfa1 results in a complete lack of bone formation owing to maturational arrest of osteoblasts. Cell. 1997;89(5):75564. [PubMed: 9182763].

53. Zhang ZY, Teoh SH, Chong MS, Schantz JT, Fisk NM, Choolani MA, et al. Superior osteogenic capacity for bone tissue engineering of fetal compared with perinatal and adult mesenchymal stem cells. Stem Cells. 2009;27(1):126-37. doi: 10.1634/stemcells.2008-0456. [PubMed: 18832592].

54. Mayer-Wagner S, Hammerschmid F, Redeker JI, Schmitt B, Holzapfel BM, Jansson V, et al. Simulated microgravity affects chondrogenesis and hypertrophy of human mesenchymal stem cells. Int Orthop. 2014;38(12):2615-21. doi: 10.1007/s00264-014-2454-3. [PubMed: 25030964]. 